\title{
Boosting Voice Equity at Workplace: An Implication of Tertiary Education on Mature Women Work Performance in Rwanda
}

\author{
Safari Kambanda*, Kabwete Mulinda Charles, Kagwesage Anne Marie', Murenzi Janvier \\ University of Rwanda, B.P. 117 Butare, Rwanda \\ *Corresponding author: kamsafari@yahoo.fr
}

\begin{abstract}
Before 1994, Rwanda education policy knew some selection barriers to access tertiary education. Thereafter, it liberated the access allowing many higher private learning institutions to open their doors. This paper analyzed late tertiary education impact on mature women students. The impact regards acquired knowledge, skills and capacity that boosted their voice equity to better perform at workplace than before. The research embarked on Bandura's [1] social learning theory (or social cognition theory) that proves how people with high self-efficacy master their feelings and thoughts, are self-directed and motivated to accomplish their targets. The study followed a qualitative approach including interviews with 18 mature women and 104 who filled the questionnaires. All the participants were in fourth year, between the ages of 30-45 and selected from five higher private and public learning institutions but following different programmes. The findings show that their self-efficacy beliefs as a social cognition construct empowered their capacity to perform specific duties through personal goal setting. Further, tertiary education, from the majority of their views and perceptions, increased their self-esteem and trust, rendered them effective human capital in their day-to-day duties, enhanced their personal fulfillment and awakened them to be more participative in different social, political, economic spheres etc.. In addition, they learned to link challenging goals of studying to strong commitment of being good performers at work, raising confidence in colleagues, employers, neighbors and avoiding failures but creating attitudes of serenity and scrutiny to approach difficult situations.
\end{abstract}

Keywords: mature women education, capacity- building, equity of voice, self-esteem work performance, justice and social welfare

Cite This Article: Safari Kambanda, Kabwete Mulinda Charles, Kagwesage Anne Marie', and Murenzi Janvier, "Boosting Voice Equity at Workplace: An Implication of Tertiary Education on Mature Women Work Performance in Rwanda." American Journal of Educational Research, vol. 6, no. 1 (2018): 18-26. doi: 10.12691/education-6-1-3.

\section{Introduction}

The new education policy in Rwanda liberated education from 1994. It expanded the only higher public institution to many more. The policy encouraged the private sector to create some other private higher learning institutions. The age factor was no longer a selection criterion. This increased access to education that for long knew different selection barriers. Rwanda needs qualified and skilled human resource through its Economic Development and Poverty Reduction Strategy MINECOFIN (EDPRSII) [2]. The need is to address the imbalance in the supply and demand of skilled labour force. Progress has been made to ensure available skilled workers, but still education is a bridge to break the gap. It is observed that mature women had little or no access to tertiary education before 1994 genocide against Tutsi. This imbalanced gender capacity, disempowering women positions in the socio-economic transformation of the country. To this paradigm, the worth of investigating the influence of late tertiary studies on mature women is crucial. It explores their capacity to participate in decision making, problem solving as skilled workers for life transformation. The exploration involves how studies boosted their voice equity at workplace and the country's human resources in general.

MINEDUC ESP [3] recognized gender as an obvious area where there has been inequality in education. This inequality has been pronounced between sexes despite some improvements as the level of education gets higher. The tendency is reinforced in many more spheres of the country management and leadership. Many more men than women are in decision-making roles that reflect less opportunity to reach higher positions in employment. Thus, education capacity building increases power earning to combat current and future poverty through competencebased work productivity. It further creates self-confidence, equity of voice, participation in service delivery, economic empowerment, good governance, justice and social welfare at work place. This makes citizens effective human capital for socio-economic transformation. 


\section{Significance}

Obama [4] stated that the future must not belong to those who bully women. It must be shaped by girls and women who go to school. Further, it must be done by those who stand for a world where our daughters can live their dreams just like our sons. Obama emphasized that sustainability, progress depend on success of women when they are provided equal rights, access to education. Therefore, despite their age they get opportunities and capabilities to participate in different socio-economic activities.

The UIE [5] and (PROAP) International Seminar on Women's Education and Empowerment confirmed women's education to be a key to development objectives. Recently, empowerment has been tied to the range of activities undertaken by and for women in different areas, education included. Further, from the 1975 UN Declaration of the Decade of Women, attention and action was put on women. Their education targeted to raise consciousness and skills acquisition. Education stayed the field most of women's organizations, government agencies, and different international donors emphasized. The focus was to make women become aware of their societal consideration and state through education. Once known their level of education and target would enhance it, then the process of empowerment would spring from there.

Education policy, in the 1994 post-genocide period, is trying to address the issue of "Education for All". It seeks to give opportunities to gender balance an equal access to education from primary to higher levels. Though, this research intends to investigate the influence of university education to empower mature women students' voice equity on duty. It aims to see how education facilitates them to become skilled agents of their community social development. The study focused on fourth year's students' empowerment in both public and private higher learning institutions but who were on duty. Significantly, the research area was still unexploited in Rwanda with regard to historical education background. Belatedly, it helps to assess whether or not the beneficiaries became more problem-solvers, effective and efficient practitioners. Policy-makers, public and private education leaders, education stakeholders, and mature university women students would benefit from the research for future agenda.

\section{Research Question}

This research investigates the influence of tertiary education on mature women's voice equity rise in Rwanda. The investigation overarches: (1) how late university education contributed to empower mature women students to become skilled agents for better performance at work, (2) how mature women students perceived university studies have rendered them more knowledge-based workers, (3) how university education transformed mature women students into problem solvers, effective practitioners and decision-makers at workplace.

\section{Data Collection/Methodology}

This research is a case study that followed a qualitative perspective. Yin [6] understands a case study as an empirical inquiry. It investigates contemporary phenomena within its real-life context when the boundaries between phenomena and context are not clearly evident. The inquiry uses multiple sources of evidence to study the phenomena. Paton [7] contends that an understanding of a social phenomenon is best achieved by selecting information-rich cases to illuminate the questions under study. For, Lincoln \& Guba [8] it is a fitting capstone for the naturalistic inquirer. It helps to catch the reality in its original form. Such research involves studying individual cases, often in their natural environment. In essence, participants were asked to share acquired experiences during their education and careers. This reflected on how they thought they were rendered critical thinkers in the socio- development of the country.

This research was conducted in five Rwandan public and private higher learning institutions. These are: University of Rwanda in its two colleges (college of Business and Economics, Gikondo campus and the College of Arts and Social Sciences, Huye campus), Institute of Applied Sciences (INES in Musanze district), the Institute of Kabgayi (ICK in Muhanga district), the Institute of Agriculture, Technology and Education (INATEK in Ngoma district).

The site choice was based on an attempt to reach as many participants as possible and in different parts of Rwanda. The selected mature women students were 150 ranging (both for interviews and questionnaires) from the age of 28 to 53. The majority was over 30 to almost 45 . Data collection followed two stages. One was interviews in three institutions expecting to get 20 participants from 23 June 2015 to 30 December 2015. Only 18 of them were met due to participants' availability because they were working and studying. The second was a distribution of semi-open questionnaires to 130 students from September 2016 to 20 January 2017and only 104 were filled. The two approaches were used in order to triangulate the perceptions from interviews and questionnaires. Informants enjoyed the freedom of linguistic choice among the three administrative languages used in Rwanda (Kinyarwanda, English and French.) During data collection all the informants were in the final year undergraduate level. The researcher expected those participants had enough experience from the acquired knowledge and skills than the ones in lower levels. Participants' names from interviews have been coded for the sake of anonymity. Further, questionnaire data were grouped under themes and tables to facilitate their analysis.

\section{Literature Review/Theoretical Framework}

The crucial perception articulated by most of older women students on their empowerment through education is personal fulfillment or self-fulfillment [9]. For O'Brien \& Whitmore [10], personal fulfillment is often understood by older women students as having a life of one's own. The author observed that one married woman, in her 40s, responded to the question of why she came back to university. The respondent summarizes the recurrent theme of needing both a separate identity and a new direction which includes a career. Self-fulfillment means 
gaining control over one's own life and decisions through education. Linked to the notion of control is empowerment so that by gaining control, women are empowered. Achieving more control and becoming empowered is crucial and essential to fulfill tasks for nontraditional women i.e. mature women students. In fact, learning should then be an empowering experience, particularly for women over the age of 35 .

Boosting mature women voice equity interrelates to empowering them. It is creating opportunities to make them fully participants in the various socio-economic spheres of the nation and internationally. Attaining such objective requires enhancing women access to education. This is an important tenet for their self development, the family, the country and the world in general. Empowerment is referred to as the expansion in people's ability to make strategic life choices where this ability was previously denied. Changes in the ability to exercise choice can be thought of in terms of changes in three inter-relating factors that make up choice i.e. (1) resources: as the condition under which choices are made; (2) agency: that founds the heart of the process to choose and (3) achievements: that constitute the outcomes of choices [11,12]. Differently, Alsop, R. and Heinsohn [13] argue that empowerment is the capacity to make decisions and to convert them into desired outcomes Bordat, W.S.; Davis, S. S. \&Kouzzi, S. [12] contend that empowerment increases people's control over their lives as a process. It means to improve individual's bargaining positions, having a voice as a goal to enhance income, assets, health, security, and freedom that imply productivity, justice and social welfare.

Oyitso \& Olomukoro [14], Okemakinde [15] say that education is recognized as the cornerstone for sustainable national development. To integrate women into development process, they need quality education to become co-partners in national development. Research defines educated employees as those individuals who hold at least bachelor's degrees. These degrees are necessary for entry into many higher paying occupations after the academic credentials an individual has obtained $[16,17,18]$.

Education renders ability, knowledge in terms of an individual's power, strength, or capacity to perform a task $[19,20]$. Education and work experience are the two forms of human capital individuals are most likely to acquire during their careers $[18,21,22,23]$. Individuals with higher levels of education have both greater fluid and crystallized intelligence $[24,25]$. Fluid intelligence refers to the capacity of working memory, abstract reasoning, attention, and processing complex information. Crystallized intelligence refers to general knowledge, extent of vocabulary, and verbal comprehension related to vocational and a-vocational topics and area [26]. Education stimulates the development of students' minds and promotes the growth of crystallized intelligence. Individuals with more education are likely to have greater in depth analytical knowledge (crystallized intelligence) as well [24].

Research on women capacity building and empowerment may cover many significant research areas, having diverse meanings to different people. Movements to fight against illiteracy have been supported worldwide and research recognizes the interrelation between women status and education [27]. Murtaza [28] states that the movement for improving women's status has always focused on education. This has been considered as the paramount tool for changing women's subjugated position in the society. Higher education is the leitmotiv to qualify women to become leaders in their society and role model for younger girls. Inayatullah an MP in Pakistan, denounces that:

"the UNESCO accords the greatest importance to the role of women graduates who, because of their training, constitute part of a country's skilled human resources.They are therefore, in a position to make a significant contribution to the process of sustainable human development. They contribute in various waysas professionals within their chosen domains of expertise, as decision makers through their influence on policy issues related to social, economic and cultural development and through their participation in family and community life".

Herz \& Sperling [29] sustain higher education as a powerful instrument that mediates social change to women empowerment. This social change links to O'Brien and Whitmen's [10] explanation of the three human empowerment phases and their components. These include (1) at the individual level: self-confidence, feelings of efficacy and self-worth, learning (i.e. knowledge and skills) and productivity are observed. Regarding the (2) group level, the authors put forth the reinforcement of self-confidence and efficacy, the sense of belonging and interpersonal relationships, trust, group cohesiveness and collective analysis and reflection. Last is the (3) environmental phase that relates to increased resources, accountability, raised expectations and organizational growth.

Bandura's [1] social learning or social cognition theory underpins the theoretical framework of this study and its contribution in the area of work performance. Empirical literature strongly emphasized the relevance of social learning theory, the link it provides among self-efficacy, motivation and task performance [30]. The author notes self-efficacy as a social cognition construct i.e. social learning. He defines it to be a person's self-belief in his/her capacity to perform specific duties through personal goal setting.

Jole, M.; McCormick, M.J.; Tanguma, J.; LópezForment, S.A. [31] say that self-efficacy theory has inspired a very large and diverse body of empirical research. This has been introduced by Bandura [32] who analyzed the impact of self-efficacy perceptions on work performance. Beliefs about personal capabilities were found to affect academic achievement, career choice, entrepreneurship, decision making, organizational functioning, stress tolerance, etc. [1]. In sum, confidence, self-efficacy in one's task-specific abilities were determined as important causal variables to understand and improve performance in achievement settings.

Bandura [1] sustains self-efficacy as a paramount tenet of social cognitive theory. He understands it as the belief, confidence a person has to successfully behave productively. Once s/he is highly self-efficacy leveled, the more $\mathrm{s} /$ he perceives to be able to execute the required behavior to obtain a particular outcome. The author stresses the importance of social cognitive theory and notes that success experiences raise self-efficacy. Contrary, 
successive weaknesses lessen it. Bandura, [33]; Schwarzer \& Luszczyuska, [34] believe that people with high self-efficacy master their feelings and thoughts, and are self-directed and motivated to accomplish their targets. Effective and capable individuals are mostly supportive in the society than those who appear to feel unskilled. Lunenberg [35] sees Bandura's [36] self-efficacy theory as a widely posited theoretical foundation. Bandura [1,37] Stajkovic \& Luthans [38], Lunenberg [35] regard self-efficacy as a proven record of application in the workplace.

Bandura [39] puts forth three interconnected ways in which self-efficacy impacts learning for work performance. An individual with high self-efficacy likely sets high personal goals. Oppositely the employee with self-efficacy low level thinks of low goals setting. This view shows the first way self-efficacy influences the goals that individuals choose for themselves. Also, self-efficacy influences learning and the effort individual exert on the job. Secondly, employees manifesting high self-efficacy level work harder to increase the capacity to afford new duties. This behavior arises from their confidence and efforts to perform successfully. Third is how self-efficacy impacts the persistence with which people try new and difficult tasks. Such behavior increases high self-efficacy to persist in problem-solving and having a stand in difficult situations. However, individuals with low level of self-efficacy present incapacity and tend to quit. Bandura [1] and Locke [40] share the views that self-efficacy is a powerful determinant of job performance.

Manasseh, N. Jroegbu [30] strengthens social learning theory on work performance as follows:

"Strong self-efficacy beliefs enhance human accomplishment and personal well-being in many ways. People with a strong sense of personal competence in a domain approach difficult task in that domain as challenges to be mastered rather than as dangers to be avoided. They have great intrinsic interest in activities, set challenging goals and maintain a strong commitment to them. They heighten their efforts in the face of failure; more easily recover their confidence after failures or setbacks. They attribute failure to insufficient effort or deficient knowledge and skills which they believe they are capable of acquiring. High self-efficacy helps create feelings of serenity in approaching difficult tasks and activities, Manasseh Jroegbu [30]"'.

Social cognitive theory Bandura [1] enlightens the rationale to analyze the perceptions and experiences of Rwandan mature students on duty. It uncovers variables or constructs that may influence their self-efficacy at workplace from late tertiary education capacity building. Jroegbu [30] contends that different variables like the nature of the work, intelligence, personality, skills level, motivation, supervision, training, level of the worker, education, etc. impact the relationship between self-efficacy and work performance. Bandura [1] says people who regard themselves as highly efficacious act, think and feel differently from those who perceive themselves as inefficacious. They produce their own future, rather than simply foretell it. This understanding helps to sort out the experience of the informants, the level on which tertiary education impacted their self-efficacy at workplace.

\section{Analysis and Discussion of Findings}

This section analyses the testimonies of mature women students on how they felt impacted by late tertiary education despite their old age. The findings derived from 18 interviewed women, and 104 filled semi-open questionnaires. The analysis embarked on how education raised mature women students' voice equity at workplace. It includes self-efficacy, personal-fulfillment and their awareness rise for better performance at workplace. This paradigm relates to their recovered societal consideration and state from the access to tertiary education that they were for long deprived of. The first stage below is an analysis of data from 18 interviews.

\section{Mature Women Students and Voice Equity Rise Testimonies}

Researchers stipulate that education stimulates the development of students' mind and promotes their growth. To this perception, F.B. testified how studying at old age opened her mind. She is in year four economics and runs her own business as an accountant. She uses the skills she acquired at the university. Studying raised her voice, her fellows and clients respect and trust her due to delivered services. She feels to be highly leveled because she does what she really masters.

N.G. works in a supermarket for a private person to survive and pay her university fees. She seemed to be frustrated and scared to answer for fear to lose her job. Finally, she said nothing was noticed with regard to her voice equity because she lacks so many advantages and rights she could gain relatively to her education level.

"You know... private sector employers manage as they feel. They never care about studies levels because some of them are less educated people. They sometimes envision their own interests and this hinders the company's effectiveness, workers justice and social welfare."

However, the respondent was not disappointed, expected to free herself because she felt to be competitive on the labour market.

P. R. is a teacher and school council member. She testifies on power earning increase. She confirmed to be the only under leveled in the team and was always frustrated. She always felt sad during meetings, could not speak fearing to suggest wrong ideas. But today she is mind opened, full of hope to have a say in discussions that concerns the school management. This raised her selfesteem and feels equal to other team members.

P.S stated that the nowadays labour market needs educated people and felt she was among them. To quote her, P.S. said:

"I am a secretary at the district level, have been elected to be one of the district task force members due to my education level. I am esteemed and take part in different activities in the district despite my job position. I think 
the future is now open to me in this competitive world. In fact higher education rendered me more experienced and useful to the community."

Further, it was observed that tertiary education impacted the awareness rise of leadership capacity in P.S. testimonies.

M.R studied tourism in secondary school and went to university late. She now works in one of the big hotels in Kigali as a head of protocol. She insisted on her voice equity boost because of having increased her knowledge in sociology. She is now self-confident, thinks twice before embarking on any idea. More on that, she is fearless to stand in front of her audience and have a word. However, there were some duties her boss could not charge her before. She was always afraid of facing him. She each time thought she could be asked to do something that was beyond her capacity.

An archivist, K.M., proved her skills enhancement and life transformation at workplace in the following quote:

"Before studying I was scaring about my job, feared to be fired due to my education level. I am now confident and feel my stand is empowered because my employer sees that I really do what I am capable of. My level has stepped up and colleagues always need my daily intervention. The consideration I now have is value added."

Further P.C. also works as a district archivist in a rural area. She shows how educating a woman becomes a mediation of social change. She is now highly considered because University studies turned her into another new person. People always wait for her views because they consider her as a skilled and experienced worker. She has been proposed to stand for the women association committee at the district level in the coming elections.

R.M. studies water management and considers tertiary education as an expansion of efforts in people's ability, especially old women, to help them make strategic life choice. She confirms she really achieves her duties without stress and frustration. For her, self-esteem is built on knowledge advancement and the step someone has made. Education made her a respectful woman because of the degree she expects to get. She says: "I do critical reasoning before acting and never decide abruptly. My acting reflects personal thinking and impacted my behavior in my work community".

Z.A. as a future lawyer testified high self-efficacy as follows:

"I feel esteemed at the university; have been elected among the student association leadership committee. I competed with younger and more active students. They did not consider my old age but taken into account my efficacy and intellectual capacity. I think I have overcome the former limitations that tied me and pushed me to be always behind the curtain."

O.F. is also doing law but from a different institution and confirms to be effective and good service deliver. She finds tertiary education as a cornerstone for sustainable development. She confirms that self-confidence and productivity are interlinked. No one can harm or hinder her rights as a future lawyer who knows what to do and to avoid. Studying improved her mind fitness. She feels competitive, and capable of investigating different crimes. She is helping powerless people with regard to their rights and duties and promoting social justice, equity and social welfare.

Another woman stated:

"Studying raised and awakened me profoundly, said G.R. who studies accountancy. I used to work as an ordinary woman in a restaurant but now my education experience leveled me to become the accountant. My employer never doubts to delegate me in different meetings. He gives me some other responsibilities like purchasing and motivating others for the sake of the institutions benefits. I am esteemed and no longer hesitate to provide constructive suggestions."

S.V. is a future biotechnologist. University studies leveled her to participate in the decision-making and problem solving process at workplace. She said:

"I think I am among the rare women who study biotechnology because many are afraid to afford science. I am gaining sufficient knowledge and I am capable of doing what I could not before. The capacity I have raised my say and participation in each Mondays weekly work plan. I am no longer an absorber of what comes from others but a contributor in my institution's productivity."

M.B. is a secondary school teacher who thought she could not afford university studies because of her old age but now proved a sense of high self-reliance. Some of her colleagues resisted to start with her, now has become the role model as some registered two years after her. She confirmed that even though she has not yet finished, she always entertains her students. She encourages them to work hard in order to become the leaders of tomorrow. Her participation is of paramount importance. Her voice is no longer underestimated.

P.M. found that studying at the university cannot be taken for granted. Higher education empowers, leads to self-efficacy and competence. It specifically happens to people who were desperate like her due to the country background that could not ease access to tertiary studies. P.M. stated to be respected at workplace and home. She shares the household assets management with her husband. "You know... educating a woman is empowering the country's socio-economic development. This emphasizes a remarkable social transformation, productivity not only at workplace but also extended to the family and community."

R.W. is a cell executive studies law. She reported to be in good terms with the population. She expresses good governance and good service delivery attitudes than before. Studying raised the community's trust in her because of how she collaborates with the population. She reflects to be more experienced in day-to-day customary conflict resolution. Her voice and advice are now heard and implemented. Further, she added that her knowledge empowered her relationships at workplace for social wellbeing of the population she leads.

P.K. feels acquired leadership qualities due to the management courses she learnt at the university. She addressed her perceptions as follows:

"I am now capable of settling any kind of difficulty I face at work. The transformation I brought in my work is that I do it with scrutiny avoiding mistakes in accountancy. Studying awakened me in the sense that I have got a new direction. I have become a self-directed 
woman capable of practicing what I learnt. This made me an innovation-oriented woman who runs her business in a successful manner than before."

R.A. felt elevated to be a skilled agent of the community social development. After studying agriculture in secondary school she continued at the university and is now working at the cell level as an adviser. Now, she feels advanced in her doings, gained more skills which really transformed her and made her innovative. She has her own plot, makes research in preparing seeds, helps people to manage their lands and brings them reliable and fertile seeds during the planting season. This increased her income and copes with the Rwandan Government policy of self-reliance. She is no longer depending only on the meager wage public service employees get.

Another participant said:

"I am learning sociology said K.T. I learnt time management and strategic planning attitudes. Higher education transformed my working strategy. I am still teaching and before going at the university the school had a problem of high pregnancy rate among young girls. Now I have initiated a mixed club of boys and girls. The club changed the school reputation and we went on even sensitizing those who dropped out because of pregnancy to come back. I have improved my professional ethics. I take care of people who come to me and make sure that they are satisfied with the provided service."

Section two embodies the views from questionnaires. Explicitly the findings confirm the beliefs and confidence mature women students have had on their successful performance. The findings comprise te ways they have been empowered at work; their voice equity and stand that have been boosted. They include feelings of innovation, decision-making and problem solving behavior. Further is the enhancement of self-esteem, self-efficacy and trust recognition.

Table 1. Knowledge and skills-based empowerment

\begin{tabular}{|c|l|c|c|}
\hline \multicolumn{1}{|c|}{ AREA } & Frequency & Percentage \\
\hline 1. & $\begin{array}{l}\text { How tertiary education increased } \\
\text { your power to achieve expectations } \\
\text { at work }\end{array}$ & 24 & 23.07 \\
\hline 2. & $\begin{array}{l}\text { How higher education studies } \\
\text { made you proud of your } \\
\text { contribution at work }\end{array}$ & 31 & 29.80 \\
\hline 3. & $\begin{array}{l}\text { How acquired skills and } \\
\text { knowledge leveled you to } \\
\text { successfully achieve duties }\end{array}$ & 40 & 38.46 \\
\hline 4. & Yes responses with no details & 6 & 5.76 \\
\hline 5. & No answer & 3 & 2.88 \\
\hline & Total & 104 & 100 \\
\hline
\end{tabular}

Fieldwork data: September 2016 to 20 January 2017.

Questionnaire analysis embarked on power increase, capacity building through tertiary education to achieve expectations on duty. Many of the respondents recognized that access to higher education awakened them to be self-directed and find their own solutions. Time management, doing the right things at the right time became their target to better perform. They provided the best of their full potential in their institutions and the surrounding community. They privileged collaboration, teamwork than isolation. Listening to others was a weapon to overcome any hindrance to effectiveness and expectations. Studying at the university changed a lot in their work life. Many felt intellectually empowered and comfortable with their employers and still expect more as they are completing studies.

Data show that looking at how their social consideration was before studying they found so many differences and were proud of their contribution at work. They proved to be stable in their different positions with regard to their capacity and the state of mind they felt on job. One of them testified to be very satisfied because her employer recognized her capacity. He promoted her to the position of his restaurant accountant while before she was an ordinary waitress.

Skills and knowledge are keys to successful service delivery. It is a bridge that connects employees to the employer and their customers. Therefore, they create a good work climate conducive to better performance. As shown in the above table the most majority of the respondents affirmed they were transformed into proud workers, efficacious contributors. They were no more in an always need of supervision but became self-directed staff. They scrutinize and use their capacity to achieve their daily duties in a successful manner.

Nevertheless, the findings point out some respondents who were still in between. They could not justify their empowerment level in relation to the gained skills. They seemed not to be capable of linking what they were doing and their different jobs. This is because their programme was different from their jobs but was studying for getting new better positions. Simultaneously, some but few did not provide answers. They were jobless during the interview period but were full of hope. They expected to compete on the labour market than before. Here they felt they were no longer frustrated of their intellectual weakness like before studying.

Table 2. Mature women voice equity increase at workplace

\begin{tabular}{|c|l|c|c|}
\hline & \multicolumn{1}{|c|}{ Area } & Frequency & Percentage \\
\hline 1. & $\begin{array}{l}\text { How do you consider education } \\
\text { raised your voice and stand at } \\
\text { workplace }\end{array}$ & 35 & 36.65 \\
\hline 2. & $\begin{array}{l}\text { How is your personal ability to } \\
\text { make strategic life choice with } \\
\text { regard to leadership capacity rise }\end{array}$ & 32 & 30.76 \\
\hline 3. & $\begin{array}{l}\text { How has education improved your } \\
\text { bargaining position and enhanced } \\
\text { freedom at workplace }\end{array}$ & 31 & 29.80 \\
\hline 4. & Yes with other explanations & 4 & 3.84 \\
\hline 5. & No answer & 104 & 1.92 \\
\hline & Total & 2 & 100 \\
\hline
\end{tabular}

Fieldwork data: September 2016 to 20 January 2017.

In general the findings show that education boosted the informants' personal fulfillment. For voice equity and stand, a majority of these interviewees contended that they were no longer blind absorbers of other people's feelings or attitudes. However, they narrated a strong mind change and inner transformation of participating in different work debates, meetings and conferences. They developed a great sense of audience conviction, traced their selfposition and stand. One woman, a student in business and 
management, confirmed that her employer now trusts her even if she has been working there for long. Her employer may today delegate her in business meetings at the level of the district. She confirmed to be in good term with the employer because of the good run of the enterprise and marketing she is doing. It has raised her voice at workplace and the reputation of the company.

Analyzing the personal ability, leadership capacity rise to make strategic life choice, many participants proved they learnt to fly with their own wings. They are stable with less life stress, have improved self leadership and behavior, over control of their doings and prevent work conflict. They intervene in the community problem resolution, and participate in the socio-economic development and welfare of their society. A cell executive officer testified that she has been elected as a district advisor. The reason is that she is now skilled, competent and expects to go far and compete for future other leadership positions in the district or elsewhere at the end of her studies.

Education opens many doors and elevates one's bargaining position, confirmed a woman who was a secondary school teacher but is now ending her fourth year in law. She is working in a private law cabinet. Most of the time she meets people at the field work, awakens some of them regarding human rights and freedom. She even helps people with less financial means at the court. Though, most of the women confirmed they have been empowered and are ready to improve their freedom right state and that of their mates. This new life style brought reputation to them, increased their earnings. One hopes to start her own cabinet and help as many people as possible especially women in order to push them feel self-confident and self-reliant. She thinks her knowledge will help to prevent poverty in families and reduce conflicts between men and women, parents with children and even with extended family members.

Table 3. Innovation and Problem-Solving Enhancement

\begin{tabular}{|c|l|c|c|}
\hline \multicolumn{1}{|c|}{ Area } & $\begin{array}{c}\text { Respondents } \\
\text { Frequency }\end{array}$ & $\begin{array}{c}\text { Answer } \\
\text { Percentage }\end{array}$ \\
\hline 1. & $\begin{array}{l}\text { How do you believe you have } \\
\text { brought innovation and } \\
\text { transformation at workplace }\end{array}$ & 59 & 56.73 \\
\hline 2. & $\begin{array}{l}\text { How do you perceive late } \\
\text { education improved your } \\
\text { decision-making and problem } \\
\text { solving stand at workplace }\end{array}$ & 40 & 38.46 \\
\hline 3. & Yes with no explanation & 3 & 28.80 \\
\hline 4. & No answer & 2 & 1.92 \\
\hline & Total & 104 & 100 \\
\hline
\end{tabular}

Fieldwork data: September 2016 to 20 January 2017.

Innovation and transformation are an inner mind set change that is exteriorized in one's effectiveness and productivity. Due to their studies the majority of the respondents confirmed to be good performers and have become innovators and transformers. They felt capable of critically think; judge on what could benefit their company, the institution, and their business. The participants proved that their higher education access their labor force participation, raised them to be agents of social change by taking and occupying a more visible role at workplace.
They are playing a vital role in the country's economy, like paying taxes for those who work for themselves etc. Their testimonies showed that education leveled them to a new perception of self to understand others. One of the women who is studying agriculture said that she has initiated a small project of helping small farmers to get good Irish potatoes seeds. These seeds transformed the villagers' income life and productivity. Another is a teacher who testified the rise of students' success through building a culture of reading. She approached some NGOs that are working in the district and managed to get a help of some books to encourage students to increase their intellectual capacity through reading. This culture has now been expanded is some neighboring school and increased success rates in national examination.

This study shows that tertiary education boosted these mature women's awareness of laws and other circumstances that prohibit gender-based discrimination. Women improved their decision-making and problem solving capacity at workplace and where else they could intervene. Further, the big majority, as shown in the table above, noted a big change in their political, social and economic power and resources. Their participation leads to an increase of decision-making stand both individually and collectively. They are no longer implementers of what has been decided by their counterparts men as traditionally understood. However, their level of suggesting, influencing some previously taken resolutions has been self-empowered. One responded that her job position in the district has been raised from a simple cell secretary to a vice major. Her leadership position leveled her say. It increased her decision-making power and therefore, is awakening other women to overcome daily challenges of feeling frustrated and inferior to men. She added that she initiated different income generating associations across villages that increased women life style, made them capable of saving and overcome societal challenges, customs of totally depending on men. This collective mobilization improved families' social welfare as it led women to share views with their husbands. These mature women are suggesting a change in education policy that consists of encouraging mature people to join higher education. They experienced that it is never late for someone who is studying. Specifically, it benefits old women as they embody powerful capacities to boost families' economic growth and the nation as well.

Table 4. Mature women self-esteem, self-efficacy and trust

\begin{tabular}{|c|l|c|c|}
\hline \multicolumn{1}{|c|}{ Area } & $\begin{array}{c}\text { Respondents } \\
\text { Frequency }\end{array}$ & $\begin{array}{c}\text { Answer } \\
\text { Percentage }\end{array}$ \\
\hline 1. & $\begin{array}{l}\text { How do you believe your } \\
\text { education level raised your } \\
\text { self-esteem, self-efficacy and trust }\end{array}$ & 45 & 43.26 \\
\hline 2. & $\begin{array}{l}\text { How do you think university } \\
\text { studies rendered you an effective } \\
\text { human capital }\end{array}$ & 36 & 34.61 \\
\hline 3. & $\begin{array}{l}\text { How do you believe education led } \\
\text { you to personal -fulfillment, self- } \\
\text { fulfillment for the benefit of the } \\
\text { institution you work for. }\end{array}$ & 21 & 20.19 \\
\hline 4. & Yes without details & 2 & 1.92 \\
\hline & Total & 104 & 100 \\
\hline
\end{tabular}

Fieldwork data: September 2016 to 20 January 2017. 
Analyzing feelings on self-esteem, self-confidence and trust at workplace, a big number of mature women recognized personal development by setting realistic standards. Studying at the university raised the way they thought about themselves and the social consideration they had. Education decreased their depression, anxiety from lower intellectual capacity and fear to underperform. Rather it boosted a positive influence on their behavior while on duty. Self-reliance made them enjoy their career and worthiness on a day-to-day basis. A woman aged 45 confirmed the capacity to defend her choice, the ability on her know how to adjust mistakes or shortcomings and power to resist against external manipulation. Studying at the university developed in her a holistic view of optimism for a better future. She felt to have a constructive and critical thinking attitude that not only benefits her institution but the community in large.

In addition, as education is a cornerstone for human capital, these women approved dissimilarities between how they were less effective and efficient like today. They thought their level of performance is related to the level of human capital expected from their employers. Further, most of the women who still teach agreed they became aware of children's education and instruction. They collaborated with their parents; made follow ups in villages to make sure children had time to revise etc.

These women felt self-fulfilled while delivering services because their knowledge capacity was expanded and could control their own decisions and sustain them. They really proved to be capable and aware of their rise of leadership capacity. In essence, the majority stated they had no more limitations to serve their institutions. They brought in innovation and worked for the socio-economic transformation of where they lived and even beyond.

\section{Conclusion}

Late tertiary education influence on mature women students proved a great social change in comparison to the state of mind they had. Their societal consideration, equal rights to access higher education, voice equity rise, social justice and welfare for their personal fulfillment were empowered. Bandura's [1] social learning theory or social cognition theory has led this study. The theory proved the relation between self-efficacy and knowledge empowerment to better perform duties. It sustained the way people with high self-efficacy master their feelings and thoughts, are self-directed and motivated to accomplish their targets and are supportive in the society.

Education led these women to a strong sense of self-efficacy and reliance that enhanced their human accomplishment and personal well-being. It boosted their voice and stands, heightened their intrinsic feelings to perform better than before. They overcame frustration and were committed to be competence-based workers for the institutions, companies and own businesses they were working in or for. Further, from the majority of their views and perceptions, tertiary education increased their self-esteem and trust, rendered them effective human capital in their day-to-day duties. It enhanced their personal fulfillment and awakened them to be more participative in different social, political, economic etc. spheres in their respective communities. Their education raised confidence in colleagues, employers, neighbors and capacity to avoid failures but creating attitudes of serenity and scrutiny to approach challenging goals of studying to strong commitment of being good performers.

This research impacts on the necessity to think about a potential great number of mature women with only a secondary level of education that considers the age selection as a barrier to access higher education in Rwanda. Moreover, education policy makers, national and international women agencies, local administrative authorities, stakeholders in education are recommended to put their hands together and mobilize mature women who are still frustrated to afford university studies. Their education impacts the family in many ways and may also increase and empower the Education For All policy to reduce illiteracy, poverty, infant mortality, gender violence rate, pregnancy at teenagers age, drug abuse etc. Scholars have foreseen the crucial importance of education for women at any age level confirming that educating a wife is for the whole nation.

The social implication of this study is a demonstration that educating mature women renders them mediators of social change. Access to higher education empowered these women to make strategic life choice and increased their personal capabilities. This research contributed to explore the conviction mature women students may show to provide the best of their potential for the socioeconomic transformation. It elicits mature women social consideration change vis-à-vis their counterparts, policymakers, stakeholders who thought they could not afford it. The study implicates a rethinking of education policy strategy of reinforcing the access of mature women to tertiary education for those who had less chance. This may impact the awareness rise of their civil rights, leadership capacity, family income generation, poverty reduction, to mind set change for holistic development. This research contributed to show how the informants have been the pioneers of non-traditional students at tertiary education level in Rwanda.

\section{References}

[1] Bandura, A. (1997). Self-efficacy: The Exercise of Control. New York: Freeman.

[2] Ministry of Economy and Finance (MINECOFIN, 2013-2018). Economic Poverty Reduction Strategic Plan (EDPRS II) Kigali, Rwanda.

[3] Ministry of Education (MINEDUC0) (2003). Education Sector Policy (ESP). Kigali: MINEDUC.

[4] Obama, B. (2012). Speech to the United General Assembly, The New York Times, http://www.nytimes.com/2012/09/26.

[5] The UNESCO Institute for Education (UIE, 1995) and The Principal Regional Office for Asia and Pacific (PROAP). International Seminar on Women's Education and Empowerment. http://unesdoc. Unesco. Org./images/0010/001006e.pdf.

[6] Yin, R.K..1994. Case Study Research: Design and Methods. (2nd Ed.). London: Sage publications.

[7] Paton, M.Q. (2002). Qualitative research \&Evaluation methods $\left(3^{\text {rd }}\right.$ ed.), Thousand Oaks, CA: Sage.

[8] Lincoln, Y. S., and Guba, E.G. (1994). Naturalistic Inquiry. Newbury Park, CA: Sage Publications.

[9] Betz, E.L. (1982). Need Fulfillment in Career Development of Women. Journal of Vocatianal Behavior, 20, pp .53-56.

[10] O'Brien, M. \& Whitmore, E. (1986). Empowering Mature Women Students in Higher Education, McGill Journal of Education, Vol. 24 No. 3, pp.305-320. 
[11] Kabeer, N. (2001). Resources, Agency, Achievements: Reflections on the Measurement of Women's Empowerment. Discussing Women's Empowerment-Theory and Practice. SIDA Studies No. 3, Swedish International Development Cooperation Agency, Sweden.

[12] Bordat, W.S.; Davis, S.S. \&Kouzzi, S. (2011). Women as Agents of Grassroots Change: Illustrating Micro- Empowerment in Morocco Journal of Middle East Women's Studies, Vol. 7, No. 1, pp. $90-119$.

[13] Alsop, R., and Heinsohn, N. (2005). Measuring Empowerment in Practice: Structuring Analysis and Framing Indicators. Policy Research Working Paper No. 3510, World Bank. Publishing House 9/2325, Kailash Nagar, New Delhi: India.

[14] Oyitso, M. \& Olomukoro, C.O. (2012). Enhancing Women's Development through Literacy Education in Nigeria, Review of European Studies; Vol. 4, No. 4, pp .66-76.

[15] Okemakinde, T. 2014. Women Education: Implication For National Development in Nigeria. European Journal of Globalization and Development Research, 9.1, 553-564.

[16] Howard, A. (1986). College Experiences and Managerial Performance. Journal of Applied Psychology, 71, 530-552.

[17] Trusty, J, Niles, S.G. (2004).Realized Potential or Lost Talent: High School Variables and Bachelor's Degree Completion. Career Development Quarterly, 53, 2-15. Psychology, 71, 530-552.

[18] Thomas, W. H. NG. \& Daniel, C. Feldman. (2009). How Broadly Does Education Contribute to Job Performance? Personal Psychology, 62, 89-134.

[19] Hunter, J.E. (1986). Cognitive Ability, Cognitive Aptitudes, Job Knowledge, and Job Performance. Journal of Vocational Behavior, $29,340-362$

[20] Ree, M.J, Earles, J.A, Teachout, M.S. (1994). Predicting job performance: Not much more thang (general cognitive ability). Journal of Applied Psychology, 79, 518-524.

[21] Myers, M.B.; Griffith, D.A; Daughtery, P.J. \&Lusch, R.F. (2004).Maximizing the Human Capital and Skills, Journal of Business Logistics, Vol. 25, No. 1, pp. 214-232.

[22] Singer, M.S, Bruhns, C. (1991). Relative Effect of Applicant Work Experience and Academic Qualification on Selection Interview Decisions: A study of between-sample generalizability. Journal of Applied Psychology, 76, 550-559.

[23] Strober, M. H. (1990). Human capital theory: Implications for HR managers. Industrial Relations, 29, 214-239.

[24] Ceci, S.J. (1991). How Much Does Schooling Influence General Intelligence and its Cognitive Components? A Reassessment of the Evidence.Developmental Psychology, 27, 703-722.

[25] Neisser, U. Boodoo, G, Bouchard, T.J, Boykin, A.W, Brody, N, Ceci, S.J, et al. (1996). Intelligence: Knowns and unknowns. American Psychologist, 51, 77-101.
[26] Kanfer, R.; Ackerman, P. L. (2004).Aging, Adult Development, and Work Motivation. Academy of Management Review, 29, 440-458.

[27] Bhatt, S. B. and Sharma, R. S. (1992).Women's Education and Docial development.Kanishka Publishing House 9/2325, Kailash Nagar, New Delhi: India

[28] Murtaza, K. F. (2012). Women Empowerment through Higher Education in Gilgit- Baltistan, International Journal of Academic Research in Business and Social Sciences, 2(9), 343-367.

[29] Herz, B. and Sperling, G. B. (2004). What Gorks in girls' Education: Evidence and Policies from the Developing World. New York: Council on Foreign Relations.

[30] Manasseh, N. Jroegbu. (2015). Self Efficacy and Work Performance: A Theoretical Framework of Albert Bandura's Model, Review of Findings, Implications and Directions for Future Research Published online July 12, 2015 (http://www.sciencepublishinggroup.com $/ \mathrm{j} / \mathrm{pbs}$ ).

[31] Jole, M.; McCormick, M.J.; Tanguma, J.;López-Forment, S.A. (2002). Extending Self-Efficacy Theory to Leadership: A Review and Empirical Test, Journal of Leadership Education,Vol. 1, No. 2 pp.34-49.

[32] Bandura, A. (1977). Self-efficacy: Toward a Unifying Theory of Behavioral Change Psychological Review, 84(2), 191-215.

[33] Bandura, A. (1994). Exercise of Personal and Collective Efficacy in Changing Societies. In A. Bandura (Ed.), Self- efficacyin Changing Societies (pp. 1-45). New York: Cambridge University Press.

[34] Schwarzer, R. E. Luszczynska, A. (2007) Self-Efficacy. In M. Gerrard \& K. O. McCaul (Eds). Health Behaviour Constructs: Theory, Measurement and Research. National Cancer Institute Website. Retrieved June 11, 2008.

[35] Lunenberg, C. F. (2011). Self-efficacy in the workplace: Implications of Motivation and Performance, International Journal of Management, Business and Administration, vol.14, n.1, pp.1-6.

[36] Bandura, A. (1986). The explanatory and predictive scope of self efficacy theory. Journal of Clinical and Social Psychology, 4, 359-373.

[37] Bandura, A. (2004). Cultivate self-efficacy for personal and organizational effectiveness. In E. A. Locke (Ed.), Handbook of principles of organizational behavior (pp. 120-136). Malden, MA: Blackwell.

[38] Stajkovic, A. D., \& Luthans, F. (1988). Self-efficacy and Workrelated Performance: A meta- analysis. Psychological Bulletin, 124(2), 240-261.

[39] Bandura, A. (1982). Self-efficacy mechanism in human agency. American Psychologist, 37, 122-147.

[40] Bandura, A., \& Locke, E. A. (2003). Negative self-efficacy and goal effects revisited. Journal of Applied Psychology, 88(1), 87-99. 